\title{
LAYERED DOUBLE HYDROXIDES, PECULIAR AND VERSATILE MATERIALS OFFERING MANY RESEARCH AND APPLICATION POSSIBILITIES
}

\author{
PÁL SIPOS ${ }^{\mathrm{a}, \mathrm{b}}$ AND ISTVÁN PÁLINKÓo,a,c*
}

\begin{abstract}
This review article describes the major structural features of layer double hydroxides (LDHs), gives an overview of their synthetic and modification methods as well as the structural characterization possibilities both the generally used and those, which can only be used for specific LDHs. The catalytic use of these materials without calcination, i.e. the layered structure is preserved, are also highlighted. The paper places the authors' works of about the last decade in the framework of recent papers and review articles of this broad field.
\end{abstract}

Keywords: layered double hydroxides; synthetic and characterization methods; catalytic application of the as-prepared forms.

\section{INTRODUCTION}

In the ninethies of the previous century, we entered the research field of layered double hydroxides by chance. At that time, we were working with the cation-exchanger montmorillonite, mostly we wanted to find ways of pillaring it with various complex inorganic cations, and use them in shape-selective catalytic reactions [1]. Then, the idea occurred to apply organic cations instead of the inorganic ones, perhaps if they are chiral, then enantioselective/ diastereoselective catalyst may be developed. Some amino acids, their protonated versions, seemed to be handy candidates to try. Having some organic chemistry background, it was clear that amino acids have amphoteric

\footnotetext{
a University of Szeged, Institute of Chemistry Material and Solution Structure Research Group, Aradi Vértanúk tere 1, Szeged, H-6720 Hungary

b University of Szeged, Department of Inorganic and Analytical Chemistry, Dóm tér 7, Szeged, $\mathrm{H}-6720$ Hungary

c University of Szeged, Department of Organic Chemistry, Dóm tér 8, Szeged, H-6720 Hungary

*Corresponding author: palinko@chem.u-szeged.hu
} 
character, they can be deprotonated as well, then, why not use them as pillaring agents in anion-exchanger materials. To keep as close similarity to montmorillonite as it was possible, substances with layered structure were sought for. Thus, we arrived at the family of layered double hydroxides (LDHs). Even superficial literature search revealed that better not choose MgAl-LDH, since they were too popular, papers with ZnAl-LDH were significantly scarcer. The project went on, and we were able to produce amino acid pillared montmorillonite and amino acid pillared ZnAl-LDH using the protonated and the deprotonated versions of amino acids [2]. The paper was well received, since, by chance, we were among the first researchers to prepare amino acid intercalated LDHs, and this area of LDH research became popular soon after we published our results. Then, for some years, it looked like that this work was only an excursion to this area, until at the beginning of the twenties of this century, when new impetus came from an industrial collaboration. Then, we started to work with hydrocalumites [3], a subgroup of the hydrotalcite supergroup of LDHs [4]. We have learnt after conducting a thorough literature search, that the synthesis, structural modification, characterization of LDHs is very crowded area, thousands of papers are published annually, and LDHs also have many applications. From time to time excellent reviews provide with critical surveys of the area [5-18], and there are some books containing vital information both for the newcomers and the experienced researchers [19-22].

As far as their usages are concerned, we list some recent reviews, about a few important applications and application areas like drug delivery vehicles [23, 24], adsorbents [25], flame retardants [26], environmental protection [27, 28], electrochemistry and energy storage [29], photocatalysis [30, 31], catalysts after heat treatment and catalyst supports [32, 33], somewhat more about catalytic applications, when the layered structure is maintained [34-37]. This is the area we are working at.

\section{METHODS OF SYNTHESIS AND POST-SYNTHESIS MODIFICATIONS}

There are many frequently used ways of preparing LDHs, most of them are wet chemical methods [5, 38]; however, recently, increasing attention is turned towards less conventional ones, like mechanochemical synthesis methods (one- or two-step milling, in which the second step is usually wet milling) or ultrasonically-assisted mechanochemical synthesis (for recent reviews, see, e.g., refs. [13] and [17]. Ultrasonic irradiation can also be used in post-synthesis modifications efficiently. 


\section{Wet chemical methods}

The main synthetic wet chemical techniques for the synthesis of LDHs are the co-precipitation [39] and the urea hydrolysis methods [40]. In the co-precipitation method, an aqueous solution of $\mathrm{M}(\mathrm{II})$ and $\mathrm{M}(\mathrm{III})$ cations (most often two components; however, layered hydroxides with three cationic components also emerge with increasing frequency) is applied as precursor. The solution is mixed together with aqueous base (usually $\mathrm{NaOH}$ ) solution to reach the $\mathrm{pH}$ of precipitation. The urea hydrolysis method works similarly, but the urea hydrolysis, which is temperature-dependent provides the necessary $\mathrm{pH}$ value. The method affords more precise and constant $\mathrm{pH}$.

It is known that the interlayer anions can be exchanged almost at will even bulky organic or complex ones can be introduced into the interlayer space [41, 42]. Among the methods generally applied for this purpose [43] one can find wet chemical as well as mechanochemical techniques. The wet chemical methods can be direct anion exchange from water [44], aqueous ethanol or acetone [45]; co-precipitation of the components including the anion to be intercalated [46]; the dehydration-rehydration method of intercalation [47, 48]. Occasionally, ultrasonic treatment increases the efficiency of the anion exchange or allows the introduction of anions, which would be difficult without its use $[49,50]$.

\section{Mechanochemical methods}

Basically, two methods are used. One-step milling is the simpler one, in which the solid components are milled together (dry milling). This was used, for instance in the synthesis of MgAl-LDHs using planetary ball mill [51]. In the two-step milling procedure [52], dry milling was performed first with the mixtures of the solid hydroxides of the $M(\mathrm{II})$ and $M(\mathrm{III})$ ions, then, milling was continued in the presence of small amount of water (wet-milling step). The presence of water ensured the formation of the LDH, since the amount of hydroxides in the metal salts was not sufficient for this. It was also shown that using a simple agate mortar and manual grinding also provided with the LDH [53]. This "soft" mechanochemical treatment - co-grinding the constituents in a mortar with a pestle - could also be used for the intercalation of various anions [54, 55]. CaAl- [56] and CaFe-LDH [57] could be prepared by the manual grinding as well as the two-step milling methods. It was shown manual grinding worked in producing LDH; however, the transformation was only partial, while it was complete on applying the two-step milling procedure.

It was found that certain LDHs like Ca(II)Sn(IV)-LDH could only be prepared by the two-step milling procedure [58]. Both the co-precipitation method and the one-step milling operation (milling without added liquid, i.e., dry milling) failed, physical mixtures of metal hydroxides and/or carbonates were only formed. 
Upon mechanochemical treatment, the layered structure of $\mathrm{CaFe}-$ LDH) could be disordered and the deterioration steps were mapped [59]. Interestingly, the structural reconstruction of the mechanochemically disordered chloride-containing LDH was successful in distilled water as well as in nitratecontaining aqueous solution.

\section{Ultrasonically-enhanced mechanochemical method}

Ultrasonic irradiation alone is not sufficient for the synthesis of LDHs. However, when the mixture of metal hydroxides preactivated by dry milling was sonicated in the presence of distilled water, not only high-quality LDHs were formed, but various inorganic anions like $\mathrm{CO}_{3}{ }^{2-}, \mathrm{OH}^{-}, \mathrm{F}^{-}, \mathrm{Cl}^{-}, \mathrm{Br}^{-}, \mathrm{I}^{-}, \mathrm{N}_{3}{ }^{-}, \mathrm{NO}_{3}{ }^{-}$, $\mathrm{ClO}_{4}{ }^{-}$could also be introduced among the layers with relative ease $[49,50]$.

Ultrasonic treatment could be used in the synthesis of close-to-phase pure ZnAl- [60] and CaAl-LDHs [49] or even CaFeAl-triple hydroxides [61]. Its use was imperative, since after the milling step, LDH could not be observed in the product.

Ultrasonic irradiation was found to be able to regulate the crystallization process of $\mathrm{CaFe}-\mathrm{LDH}$ with chloride interlayer anions [62]. Low-performance ultrasonic irradiation provided with perfect conditions for the formation of LDH with well-developed hexagonally-shaped crystallites. At continuous emission, anion intercalation could be enhanced. At discontinuous radiation periodicity, the aggregation tendency of the particles formed was somewhat hindered. The method allowed the fine-tuning of the optical properties of the LDH samples, too.

\section{METHODS OF STRUCTURAL CHARACTERIZATION}

\section{Methods of general use}

There are many instrumental methods for the structural characterization of LDHs. Some has general applicability like powder X-ray diffractomery (XRD), infrared (mid and far) and Raman spectroscopies, X-ray photoelectron spectroscopy (XPS). These methods are largely available and relatively easily accessible even in any not so well-equipped research places. They provide with indirect information about the layered structure (XRD), and certain parts of the $\mathrm{LDH}$ like hydrogen bonding network of $\mathrm{OH}$ groups, interlayer anions, surface-adsorbed carbon dioxide, skeletal vibrations (vibrational spectroscopies), oxidation states of the cationic components (XPS). XRD is the major tool in structural characterization, since LDHs have typical X-ray traces, and certain crucial data can be deduced from the diffractograms like the basal distance (interlayer space plus the thickness of one layer) and its change due to 
functionalization. Indexing and identifying the diffraction patterns can be done with the help of the JCPDS (Joint Committee of Powder Diffraction Standards) database.

LDHs give typical response on heat treatment. Three water types can be separated on thermal treatment. Thermogravimetric measurement usually reveal three distinctive forms of water molecules. On gradually increasing the temperature of heat treatment one can remove the physically adsorbed water molecules $\left(100^{\circ} \mathrm{C}-150^{\circ} \mathrm{C}\right)$, the interlayer water molecules are next $\left(175^{\circ} \mathrm{C}-325^{\circ} \mathrm{C}\right)$, finally, the dehydration of structural $\mathrm{OH}$ groups and their closely associated (hydrogen bonded) water molecules takes place $\left(350^{\circ} \mathrm{C}-475^{\circ} \mathrm{C}\right)$. The latter are often called 'structural water', although it exists in the form of $\mathrm{OH}$ groups in the layer, but it becomes water on dehydration. The water forms can be distinguished with dielectric relaxation spectroscopy (DRS), and rehydration of the dehydrated LDH can also be followed by this method $[63,64]$.

For quantitative elemental analyses, various forms of the inductively coupled plasma analysis (ICP-MS, ICP-AES, ICP-OES) are available. This information is obtained after digesting the LDH [65-69].

Synchrotron-based methods like X-ray absorption spectroscopy, resonant inelastic X-ray scattering (RIXS), high resolution powder X-ray diffractometry, etc. are available in many places in the world, and accessible through obtaining beamtime after successful proposals. These methods provide with information on local structures or complete structural description at the atomic scale via the last method [65-68, 70-72].

Microscopic methods allow the researcher to see crucial features of the LDHs. Scanning electron microscopy (SEM) is applied for studying the morphologies of the crystals, the crystal shape can be examined and the lamellar structure of the LDHs can be observed. Obviously, changes in these features during and after treatments of various kinds can also be followed. Transmission electron microscopy (TEM), especially its high-resolution version (HRTEM) can be used for observing the layered structure directly, and, sometimes, if the orientation of the crystal allows, the thickness of the layer and the interlayer spacing can also be measured $[59,66]$. If energy-dispersive $X$-ray analysis (EDX) is possible, then, the constituents can be qualitatively analysed, and even (half) quantitative measurements are also possible. If the EDX accessory is coupled to HRTEM, then elemental maps can be made at the atomic level, i.e. the evenness of elemental distribution can be observed.

\section{Methods of limited use}

EPR spectroscopy can be used for collecting structural information if any of the components is EPR active [65,66]. 
Mössbauer spectroscopy is also a useful method providing structural information about the immediate environment of Mössbauer active nuclei. Sadly, there only a few ions (both, but more often iron(III)) are frequent constituents of LDHs [48, 73, 74].

In principle, molecular modelling is a method of general applicability; however, calculations at high theoretical levels are still problematic, because having meaningful data about a cluster representing well the LDH structure is still computationally expensive. Therefore, calculations are usually done at lower level of theory $[75,76]$, or combining molecular modelling and experimental data (XRD and TEM), and the purpose is mainly visualising the structural arrangements of intercalated complexes, for instance [65-69].

\section{CATALYSIS WITH UNCALCINED LDHS}

As it has already been mentioned, LDHs have many applications. One of the most important is their use in catalysis, mostly as catalyst precursors or catalysts in base-catalysed reactions. On calcination, the layered structure collapses and the catalytic activity of the resulting mixed oxide often increases, because of the presence of many defects in its structure.

In scarcer, but increasing number of cases, they are used in their asprepared forms, and they were found to be active, selective and recyclable catalysts in a number of synthetically useful reactions. In the followings we attempt to give a brief overview about this kind of application.

\section{Catalysts in various oxidative transformations}

As-prepared MgAl-LDH selectively oxidized the olefinic double bond of enones using $\mathrm{H}_{2} \mathrm{O}_{2}$ for oxidation [77]. As-prepared CaAl-LDH or CaFe-LDH were found to be active as well [78]. Here, the compound was 2-cyclohexene1-one, the oxidant was hydrogen peroxide, and the reaction was performed in the liquid phase in various solvents (Scheme 1). It was found that keeping the LDH structure was beneficial, since both uncalcined LDHs were more active than their calcined versions.

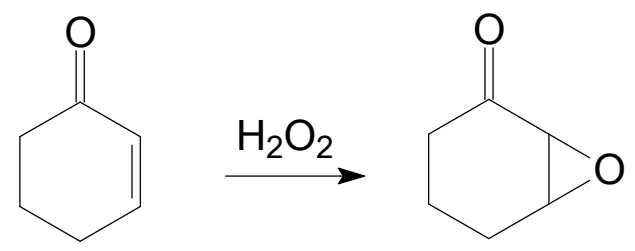

Scheme 1. Epoxidation of the $\mathrm{C}=\mathrm{C}$ bond in a cyclic enone 
$\mathrm{Ca}$ (II)Sn(IV)-LDH, which could only be made mechanochemically, worked well in the liquid-phase Baeyer-Villiger oxidation of cylohexanone (Scheme 2). Under the optimum conditions (reaction temperature: $70^{\circ} \mathrm{C}$, reaction time: $24 \mathrm{~h}$, solvent: benzonitrile) the conversion was $14 \%$; however, this was the sole product.

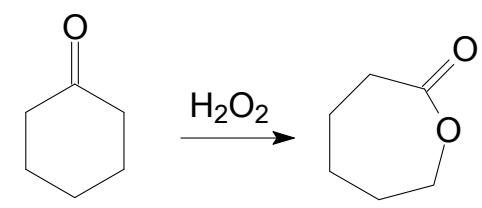

Scheme 2. $\varepsilon$-Caprolactam formation from cyclohexanone during Bayer-Villiger oxidation

The oxidative homocoupling reactions of aromatic amines (Scheme 3) as well as acetylenes (Scheme 4) were efficiently catalysed with as-prepared $\mathrm{Cu}(\mathrm{II}) \mathrm{Fe}(\mathrm{III})$-LDH in a flow reactor at moderate pressure and temperature without added materials [79]. The catalyst remained very active even after 15-h time-on-stream, and displayed very high substance tolerance.<smiles>[R][R]1cccc(N=Nc2cc#[R]cc2)c1</smiles>

Scheme 3. As-prepared $\mathrm{Cu}(\mathrm{II}) \mathrm{Fe}(\mathrm{III})-\mathrm{LDH}$ as catalyst in the homocoupling of anilines in a flow reactor

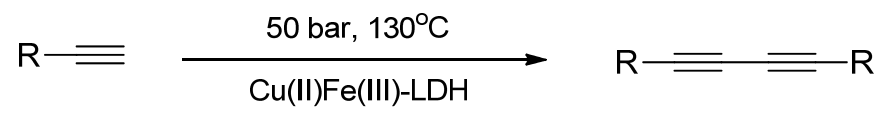

Scheme 4. As-prepared Cu(II)Fe(III)-LDH as catalyst in the homocoupling of terminal acetylenes in a flow reactor

Metal (ion) complexes intercalated in various LDHs were found to be active and selective catalysts. Mn(III)-sulfonato-salen-ZnAl-LDH intercalated material catalyzed the epoxidation of various prochiral alkenes with oxygen or even air [80-85]. Mn-salen-MgAl-LDH was efficient and recyclable catalyst in the N-oxidation of picoline [86]. Mn-porphyrin-ZnAl-LDH could catalyze the epoxidation of various olefins (cyclohexene, heptylene, phenylethylene, 3methyl-3-buten-1-ol, ethyl cinnamate and chalcone) with oxygen [87]. 
The intercalated $\mathrm{Cu}$ (II)-2,2-bipyridine-5,5-dicarboxylate complex could catalyze the oxidation of styrene, ethylbenzene and cyclohexane producing benzaldehyde, acetophenone and a mixture of cyclohexanol and cyclohexanone, respectively [88]. The intercalated $\mathrm{Cu}(\mathrm{II})$-sulphonato Schiff base complexes as well as the $\mathrm{Fe}(\mathrm{III})-\mathrm{Schiff}$ base complex-LDH composites catalyzed the oxidation of glycerol to glyceric acid [89] and the selective oxidation of cyclohexane to a mixture of cyclohexanone and cyclohexanol [90]. Recently, Mo(II) complexed with bis(4-HOOC-phenyl)-acenaphthenequinone diimine) intercalated in MgAl- and ZnAl-LDH epoxidised cis-cyclooctene, styrene applying tert-butylhydroperoxide as the oxidant with $100 \%$ conversions [91].

In our experimental work [65-68], cyclohexene and two oxidants [peracetic acid and (diacetoxy)iodobenzene] were chosen as the probe molecules for studying the catalytic properties of $\mathrm{Mn}(\mathrm{II})-$ [65], $\mathrm{Cu}(\mathrm{II})-$ [66], $\mathrm{Ni}(\mathrm{II})$ - [67] or Fe(III)-amino acid [68] (L-histidine, L-cysteine or L-tyrosine) anionic complexes intercalated in CaAl-LDH. Epoxidation is the expected main reaction channel in the oxidation reaction of cyclohexene; however, other minor products may also be formed (Scheme 5).

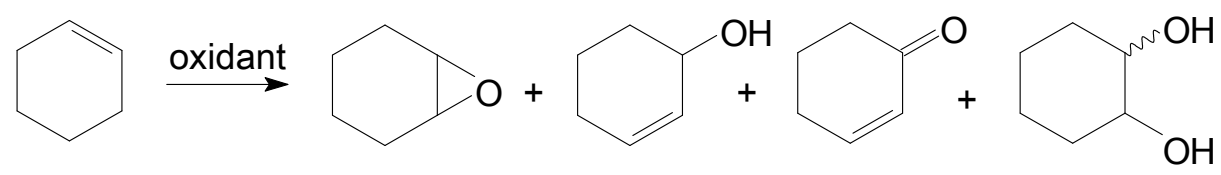

Scheme 5. The possible products in the oxidation reaction of cyclohexene

Acetone had to be the solvent, because peracetic acid does not decompose in it. The transformation of cyclohexene was significantly faster in the presence of the composites than in the blind tests (i.e. without the composites or in the presence of the LDH host only). Actually, it made almost no difference when the central ion and/or the ligands were varied. The overwhelming or the exclusive product was the epoxide, and the composites could be recycled several times with nearly retaining the original activity and composition of the product mixture.

Cyclohexene was oxidized, under similar conditions, with (diacetoxyiodo) benzene in aqueous acetone ( $5 / 95 \%$ by volume), too. The water content was imperative, since it was needed for hydrolysis, and thus the activation of (diacetoxyiodo)benzene by the following reaction [92]:

$$
\mathrm{Phl}\left(\mathrm{OOCH}_{3}\right)_{2}+\mathrm{H}_{2} \mathrm{O} \rightleftharpoons \mathrm{Phl}(\mathrm{OH})_{2}+2 \mathrm{CH}_{3} \mathrm{COOH}
$$


It was observed that the in situ formed $\mathrm{Phl}(\mathrm{OH})_{2}$, in the presence of added composites gave in close to $100 \%$ selectivity the diol even though epoxide was formed in appreciable quantities without them. The added composites acted as catalysts, and they could be recycled several times applying simple rinsing with the solvents between the repeated runs. Diol was a primary product over the fresh as well as the recycled catalysts, since the cis isomer was only found. If it had been originated from the ring opening of the epoxide, the trans isomer would have been formed.

The $\mathrm{Cu}(\mathrm{II})-[66]$ and the $\mathrm{Fe}(\mathrm{III})$-containing [68] composites were probed in the Ullmann-type etherification (Scheme 6), and they also proved to be excellent catalysts in this reaction type. Recycling was possible and easy. The reactivity was maintained even after the third recycling reaction. For regeneration, a simple rinse with toluene proved to be sufficient.

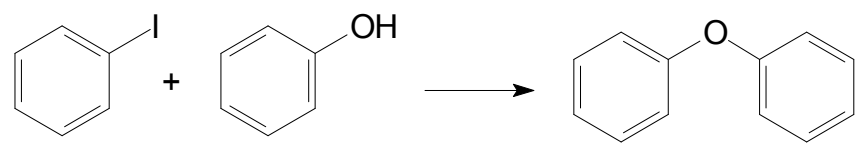

Scheme 6. Etherification of the Ullmann type

(in the original reaction, the catalyst was the $\mathrm{Cu}(\mathrm{I})$ ion $[93,94]$ )

\section{Catalysts of miscellaneous reactions}

L-Prolinate-MgAl-LDH samples were tested in cross-aldol dimerizationcondensation of benzaldehyde and acetone (Scheme 7). As it was expected, the dimerization was the main reaction (the catalyst was basic, and the temperature was low). Originally low (6\%, [95]), but later appreciable (94\%, [96]) enantioselective excess (ee) values were achieved. In the same reaction, the L-prolinate-CaFe-LDH composite did not perform so well [97], moderate ee values (53\%) could only be obtained. After recycling the activity increased; however, both the dimerization selectivity and the enantioselectivity decreased. The latter is probably due the enolization of the carboxylate ions favoured by the basic conditions [98]. Due to this reaction the chirality of the $\alpha$-carbon atom is lost.

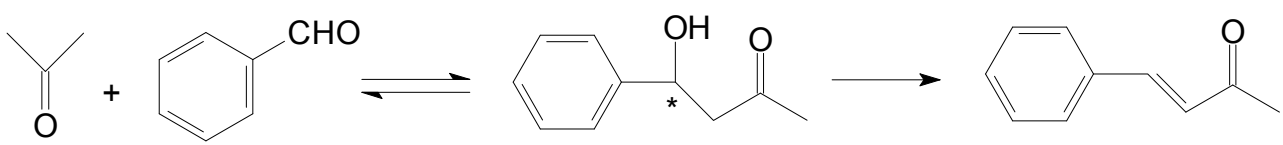

Scheme 7. The cross-aldol dimerization-condensation of benzaldehyde and acetone 
The as-prepared $\mathrm{Cu}(\mathrm{II}) \mathrm{Fe}(\mathrm{III})-\mathrm{LDH}$ actively and selectively catalysed the click reaction of organic azides and alkynes providing with 1,2,3-triazoles in a flow reactor under 50 to 100 bar pressure from room temperature to $100^{\circ} \mathrm{C}$ (Scheme 8) [99].

$$
\mathrm{R} \rightleftharpoons+\mathrm{R}^{\prime} \widehat{\mathrm{N}_{3}} \underset{\mathrm{Cu}(\mathrm{II}) \mathrm{Fe}(\mathrm{III})-\mathrm{LDH}}{\stackrel{100 \mathrm{bar}, 100^{\circ} \mathrm{C}}{\longrightarrow}}
$$<smiles>[R]Cn1cc([R])nn1</smiles>

Scheme 8. 1,3-dipolar cycloaddition between terminal acetylenes and azides catalysed with uncalcined $\mathrm{Cu}(\mathrm{II}) \mathrm{Fe}(\mathrm{III})-\mathrm{LDH}$ in a flow reactor

\section{SUMMARY AND OUTLOOK}

The research field dealing with various aspects of LDH chemistry spanning from their synthesis and modification methods through structural characterization till many kinds of applications is thriving. Thousands of papers are published annually. Here, hopefully, we were able to show recent developments of this broad field emphasizing the recently emerging area of their use as catalysts maintaining their layered structure. LDHs are versatile materials. It was also intended to show ways of their synthesis and structural modification, which is relatively easy; there are many methods available, slight and, occasionally, dramatic alterations occur. Some of them prove to be useful and are widely applied others prove to be impractical and forgotten. The authors are sure that research activity in this area will not diminish and we are going to see many new methods, with the help of which these versatile materials can be tuned to various applications even to those unknown today.

\section{REFERENCES}

1. I. Pálinkó; Á. Molnár; J. B.Nagy; K. Lázár; J. Valyon; I. Kiricsi; J. Chem. Soc., Faraday Trans., 1997, 93, 1591-1599

2. Á. Fudala; I. Pálinkó; I. Kiricsi; Inorg. Chem., 1999, 38, 4653-4658

3. I. Rousselot; C.T. Guého; F. Leroux; P. Léone; P. Palvadeau; J.-P. Besse; J. Solid State Chem., 2002, 167, 137-144

4. S.J. Mills; A.G. Christy; J.-M.R. Génin; T. Kameda; F. Colombo; Miner. Mag., 2012, 76, 1289-1336 
LAYERED DOUBLE HYDROXIDES, PECULIAR AND VERSATILE MATERIALS OFFERING MANY RESEARCH AND APPLICATION POSSIBILITIES

5. G.D. Evans; R.C.T. Slade; Struct. Bond., 2006, 119, 1-87

6. J. He; M. Wei; B. Li; Y. Kang; D.G. Evans; X. Duan; Struct. Bond., 2006, 119, 89-119

7. G.R. Williams; A.I. Khan; D. O'Hare; Struct. Bond., 2006, 119, 161-192

8. P. Nalawade; B. Aware; V.J. Kadam; R.S. Hirlekar; J. Sci. Ind. Res., 2009, 68, 267-272

9. C. Taviot-Gueho; Y. Feng; A. Faour; F. Leroux; Dalton Trans., 2010, 39, 59946005.

10. Ogawa, M.; Inomata, K. Preparation of layered double hydroxides. Clay Sci. 2011, 15, 131-137

11. Y. Lin; G. Wang; Recent Patents on Nanotechnology, 2012, 6, 169-173

12. G. Mascolo; M.C. Mascolo; Mic. Mes. Mater., 2015, 214, 246-248

13. J. Qu; Q. Zhang; X. Li; X. He, X.; Song; Appl. Clay Sci., 2016, 119, 185-192

14. M. Pavlovic; P. Rouster; T. Oncsik; I. Szilagyi; ChemPlusChem, 2017, 82, 121 131

15. V. Prevot; Y. Tokudome; J. Mater. Sci., 2017, 52, 11229-11250

16. E. Conterosito; V. Gianotti; L. Palin; E. Boccaleri; D. Viterbo; M. Milanesio; Inorg. Chim. Acta, 2018, 470, 36-50

17. S. Intasa-ard; K. Imwiset; S. Bureekaew; M. Ogawa; Dalton Trans., 2018, 47, 2896-2916

18. M.V. Bukhtiyarova; J. Solid State Chem., 2019, 269, 494-506

19. Layered Double Hydroxides: Present and Future, V. Rives; Ed.; ISBN 978-161209-289-8, Nova Science Publishers, Inc, New York, 2001

20. Handbook of Layered Materials, S. M. Auerbach; K. A. Carrado; P. K. Dutta; Eds; ISBN 0-8247-5349-6, Marcel Dekker, Inc., New York, Basel, 2004

21. Handbook of Clay Science Parts $A$ and $B, 2^{\text {nd }}$ ed., F. Bergaya; G. Lagaly; Eds; ISBN-13: 978-0080993645, Elsevier, Amsterdam, 2013

22. Layered Double Hydroxides (LDHs) - Synthesis, Characterisation and Applications, I.T. Sherman; Ed.; ISBN 978-1-63482-024-0, Nova Science Publishers, Inc., New York, 2015

23. J.-H. Yang; J.-H. Lee; H.-J. Ryu; A.A. Elzatahry; Z.A. Alothman; J.-H. Choy; Appl. Clay Sci., 2016, 130, 20-32

24. S. Saha; S. Ray; R. Acharya; T. K. Chatterjee; J. Chakraborty; Appl. Clay Sci., 2017, 135, 493-509

25. J. Qu; L. Sha; C. Wu; Q. Zhang; Nanomater., 2019, 9, 80:1-15

26. Y. Liu; Y. Gao; Q. Wang; W. Lin; Dalton Trans., 2018, 47, 14827-14840

27. P. Gu; S. Zhang; X. Li; X. Wang; T. Wen; R. Jehan; A. Alsaedi; T. Hayat; X. Wang; Environ. Poll., 2018, 240, 493-505

28. X. He; X. Qiu; C. Hu; Y. Liu; J. Disp. Sci. Technol., 2018, 39, 792-801

29. X. Li; D. Du; Y. Zhang; W. Xing; Q. Xue; Z. Yan; J. Mater. Chem. A, 2017, 5, $15460-15485$

30. L. Mohapatra; K. Parida; J. Mater. Chem. A, 2016, 4, 10744-10766

31. M.J. Wu; J.Z. Wu; J. Zhang; H. Chen; J.Z. Zhou; G.R. Qian; Z.P. Xu; Z. Du; Q. L. Rao; Catal. Sci. Technol., 2018, 8, 1207-1228

32. K. Yan; Y. Liu; Y. Lu; J. Chai; L. Sun; Catal. Sci. Technol., 2017, 7, 1622-1645. 
33. M. Xu; M. Wei; Adv. Funct. Mater., 2018, 28, 1802943:1-20

34. T. Li; H.N. Miras; Y.-F. Song; Catalysts 2017, 7, 260:1-17

35. K. Takehira; Appl. Clay Sci., 2017, 136, 112-141

36. P. Sipos; I. Pálinkó; Catal. Today, 2018, 306, 32-41

37. S.B. Ötvös; I. Pálinkó; F. Fülöp; Catal. Sci. Technol., 2019, 9, 47-60 (2019).

38. V. Tóth; M. Sipiczki; A. Pallagi; Á. Kukovecz; Z. Kónya; P. Sipos; I. Pálinkó; Chem. Pap., 2014, 68, 633-637

39. F. Cavani; F. Trifiró; A. Vaccari; Catal. Today, 1991, 11, 173-301

40. A. Inayat; M. Klumpp; W. Schwieger; Appl. Clay Sci., 2011, 51, 452-459

41. C. Forano; T. Hibino; F. Leroux; C. Taviot-Guého; Ch.13.1: Layered double hydroxides in Handbook of Clay Science, Developments in Clay Science, F. Bergaya; B.K.G. Theng; G. Lagaly; Eds; Elsevier Ltd 2006, Vol. 1, pp. 1021-1095.

42. I. Pálinkó; Nanostructures in confined environments in Encyclopedia of Nanoscience and Nanotechnology, H.S. Nalwa; Ed; American Scientific Publishers, 2011, Vol. 19, pp. 183-198.

43. A.I. Khan; D. O'Hare; J. Mater. Chem., 2002, 12, 3191-31918

44. G. Choi; J.-H. Yang; G.-Y. Park; A. Vinu; A. Elzatahry; C.H. Yo; J.-H. Choy; Eur. J. Inorg. Chem., 2015, 925-930

45. Zs. Ferencz; M. Ádok-Sipiczki; I. Hannus; P. Sipos; I. Pálinkó; J. Mol. Struct., 2015, 1090, 14-18

46. B.M. Choudary; B. Kavita; N.S. Chowdary; B. Sreedhar; M.L. Kantam; Catal. Lett., 2002, 78, 373-377

47. S. Miyata; Clays Clay Miner., 1980, 28, 50-56

48. M. Sipiczki; E. Kuzmann; I. Pálinkó; Z. Homonnay; P. Sipos; Á. Kukovecz; Z. Kónya; Hyperfine Interactions, 2014, 226, 171-179

49. M. Szabados; R. Mészáros; Sz. Erdei; Z. Kónya; Á. Kukovecz; P. Sipos; I. Pálinkó; Ultrason. Sonochem., 2016, 31, 409-416

50. M. Szabados; G. Varga; Z. Kónya; Á. Kukovecz; S. Carlson; P. Sipos, I. Pálinkó; Ultrason. Sonochem., 2018, 40, 853-860

51. V.R. Khusnutdinov; V.P. Isupov; Chem. Sustain. Dev., 2007, 15, 367-372

52. W. Tongamp; Q. Zhang; F. Saito; J. Mater. Sci., 2007, 42, 9210-9215

53. A.N. Ay; B. Zümreoglu-Karan; L. Mafra; Z. Anorg. Allg. Chem., 2009, 635, $1470-1475$

54. M. Milanesio; E. Conterosito; D. Viterbo; L. Perioli; G. Croce; Cryst Growth \& Des., 2010, 10, 4710-4712

55. A. Hayashi; H. Nakayama; Chem. Lett., 2010, 39, 1060-1062

56. Zs. Ferencz; Á. Kukovecz; Z. Kónya; P. Sipos; I. Pálinkó; Appl. Clay Sci., 2015, 112-113, 94-99

57. Zs. Ferencz; M. Szabados; G. Varga; Z. Csendes; Á. Kukovecz; Z. Kónya; S. Carlson; P. Sipos; I. Pálinkó; J. Solid State Chem., 2016, 233, 236-243

58. Zs. Ferencz; M. Szabados; M. Ádok-Sipiczki; Á. Kukovecz; Z. Kónya; J. Mater. Sci., 2014, 49, 8478-8486

59. M. Szabados; Z. Kónya; Á. Kukovecz; P. Sipos; I. Pálinkó; Appl. Clay Sci., 2019, $174,138-145$ 
60. M. Szabados; Cs. Bús; M. Ádok-Sipiczki; Z. Kónya; Á. Kukovecz; P. Sipos; I. Pálinkó; Particuology, 2016, 27, 29-33

61. M. Szabados; K. Pásztor; Z. Csendes; Sz. Muráth; Z. Kónya; Á. Kukovecz; P. Sipos; I. Pálinkó; Ultrason. Sonochem., 2016, 32, 173-180

62. M. Szabados; A.A. Ádám; Z. Kónya; Á. Kukovecz; S. Carlson; P. Sipos; I. Pálinkó; Ultrason. Sonochem. 2019, 55, 165-173

63. V. Bugris; H. Haspel; Á. Kukovecz; Z. Kónya; M. Sipiczki; P. Sipos; I. Pálinkó; J. Mol. Struct., 2013, 1044, 26-31

64. V. Bugris; H. Haspel; Á. Kukovecz; Z. Kónya; M. Sipiczki; P. Sipos; I. Pálinkó; Langmuir, 2013, 29, 13315-13321

65. G. Varga; Á. Kukovecz; Z. Kónya; L. Korecz; Sz. Muráth; Z. Csendes; G. Peintler; S. Carlson; P. Sipos; I. Pálinkó; J. Catal., 2016, 335, 125-134

66. G. Varga; Sz. Ziegenheim; Sz. Muráth; Z. Csendes; Á. Kukovecz; Z. Kónya; S. Carlson; L. Korecz; E. Varga; P. Pusztai; P. Sipos; I. Pálinkó; J. Mol. Catal. A, 2016, 423, 49-60

67. G. Varga; Z. Timár; Sz. Muráth; Z. Kónya; Á. Kukovecz; S. Carlson; P. Sipos; I. Pálinkó; Top. Catal., 2017, 60, 1429-1438

68. G. Varga; Z. Timár; Sz. Muráth; Z. Kónya; Á. Kukovecz; S. Carlson; P. Sipos; I. Pálinkó; Catal. Today, 2018, 306, 42-50

69. G. Varga; Z. Kónya; Á. Kukovecz; P. Sipos; I. Pálinkó; J. Mol. Struct., 2019, 1179, 263-268

70. D. Srankó; A. Pallagi; E. Kuzmann; S.E. Canton; M. Walczak; A. Sápi; Á. Kukovecz; Z. Kónya; P. Sipos; I. Pálinkó; Appl. Clay Sci., 2010, 48, 214-217

71. D. Srankó; M. Sipiczki; É.G. Bajnóczi; M. Darányi,; Á. Kukovecz; Z. Kónya; S. E. Canton; K. Norén; P. Sipos; I. Pálinkó; J. Mol. Struct., 2011, 993, 62-66

72. M. Szabados; Z. Kónya; Á. Kukovecz; P. Sipos; I. Pálinkó; J. Solid State Chem., 2019, 272, 227-233

73. M. Sipiczki; E. Kuzmann; Z. Homonnay; J. Megyeri; I. Pálinkó; P. Sipos; J. Mol. Struct., 2013, 1044, 116-120

74. V. Bugris; M. Ádok-Sipiczki; T. Anitics; E. Kuzmann; Z. Homonnay; Á. Kukovecz; Z. Kónya; P. Sipos; I. Pálinkó; J. Mol. Struct., 2015, 1090, 19-24

75. S.P. Newman; S.J. Williams; P.V. Coveney; W. Jones; J. Phys. Chem. B, 1998, 102, 6710-6719

76. P. Kovář; M. Pospišil; M. Nocchetti; P. Čapková; K. Melánová; J. Mol. Model., 2007, 13, 937-942

77. K. Yamaguchi; K. Mori; T. Mizugaki; K. Ebitani; K. Kaneda; J. Org. Chem., 2000, 65, 6897-6903

78. M. Sipiczki; A.A. Ádám; T. Anitics; Z. Csendes; G. Peintler; Á. Kukovecz; Z. Kónya; P. Sipos; I. Pálinkó; Catal. Today, 2015, 241, 231-236

79. S.B. Ötvös; Á. Georgiádes; R. Mészáros; K. Kis; I. Pálinkó; F. Fülöp; J. Catal., 2017, 348, 90-99

80. E. Coronado; J.R. Galán-Mascarós; C. Martí-Gastaldo; A. Ribera; Chem. Mater., 2006, 18, 6112-6114

81. S. Bhattacharjee; J.A. Anderson; Chem. Commun., 2004, 554-555

82. S. Bhattacharjee; J.A. Anderson; Catal. Lett., 2004, 95, 119-125 
83. S. Bhattacharjee; T.J. Dines; J.A. Anderson; J. Catal., 2004, 225, 398-407

84. S. Bhattacharjee; J.A. Anderson; Adv. Synth. Catal., 2006, 348, 151-158

85. S. Bhattacharjee; T.J. Dines; J.A. Anderson; J. Phys. Chem. C, 2008, 112, 14124-14130

86. L. Dai; J. Zhang; X. Wang; Y. Chen; RSC Advances, 2013, 3, 19885-19888

87. Y. Liu; Z. An; L. Zhao; H. Liu; J. He; Ind. Eng. Chem. Res., 2013, 52, $17821-17828$

88. B. Monteiro; S. Gago; S.S. Balula; A.A. Valente; I.S. Gonçalves; M. Pillinger; J. Mol. Catal. A, 2009, 312, 23-30

89. X. Wang; G. Wu; X. Liu; C. Zhang; Q. Lin; Catal. Lett., 2016, 146, 620-628

90. K.M. Parida; M. Sahoo; S. Singha; J. Mol. Catal. A, 2010, 329, 7-12

91. J. Marreiros; M. Diaz-Coucea; M.J. Ferreira; D. Pedro; P.D. Vaz; M.J. Calhorda; C.D. Nunes; Inorg. Chim. Acta, 2019, 486, 274-282

92. J.-H. In; S.-E. Park; R. Song; W. Nam; Inorg. Chim. Acta, 2003, 343, 373-376

93. F. Ullmann; P. Sponagel; Chem. Ber., 1905, 38, 2211-2212

94. F. Monnier; M. Taillefer; Angew. Chem. Int. Ed., 2009, 48, 6954-6971

95. B.M. Choudary; B. Kavita; N.S. Chowdari; B. Sreedhar; M.L. Kantam; Catal. Lett., 2002, 78, 373-377

96. Z. An; W. Zhang; H. Shi; J. He; J. Catal., 2006, 241, 319-327

97. M. Sipiczki; D.F. Srankó; Gy. Szőllősi; Á. Kukovecz; Z. Kónya; P. Sipos; I. Pálinkó; Top. Catal., 2012, 55, 858-864 (2012)

98. R. Bruckner in Organic Reaction Mechanisms. Reactions, Stereochemistry and Synthesis, M. Harmata; Ed; Springer-Verlag Berlin Heidelberg, 2010, p. 530.

99. S.B. Ötvös; Á. Georgiádes; M. Ádok-Sipiczki; R. Mészáros; I. Pálinkó; P. Sipos; F. Fülöp; Appl. Catal. A, 2015, 501, 63-73 (2015) 